\title{
EFFECT OF CURING METHODS ON STRENGTH PROPERTIES OF SELF COMPACTING CONCRETE INCORPORATED WITH METAKAOLIN AS SUPPLEMENTARY CEMENTING MATERIAL
}

\author{
Tadivaka Venkateswara Rao ${ }^{1}$, Meduri V Seshagiri Rao ${ }^{2}$, Pasumarthi Jagannadha Rao ${ }^{3}$ \\ ${ }^{1}$ Research Scholar, Jawaharlal Nehru Technological University, Hyderabad, Telangana, India \\ ${ }^{2}$ Professor in Civil Engineering department, Jawaharlal Nehru Technological University, Hyderabad, Telangana, \\ India \\ ${ }^{3}$ Advisor, ACE Engineering College, Hyderabad, Telangana, India
}

\begin{abstract}
The manufacturing of Self Compacting Concrete needs both chemical and mineral admixtures. The method of curing plays a vital role on strength and setting characteristics of SCC. Hence, this paper presents the results of an investigation dealing with the effects of curing methods on the compressive strength of SCC incorporating Metakaolin as supplementary cementing material. The SCC was prepared using 53grade OPC with and without Metakaolin as SCM. The Grades of concretes made were Standard concretes of M50 and High strength concretes of M80 grades. The compressive strength of the concrete was determined at 7 and 28days. The Curing methods adopted were the conventional method of water pond as reference and the Wax based Liquid membrane curing compound for research. The superplasticiser based on a polycarboxylic ether polymer with long lateral chains, is used to reduce water cement ratio and to improve the flow ability and filling ability of SCC. The ratio of water to binder is maintained at 0.4. It is observed that a significant loss in strength for High strength concretes of M80, around 25\%, at 28 days of Wax based liquid membrane curing to that of Water curing. There is no significant change in compressive strength for the standard concretes of M50 grade using only 53 grade OPC at 7 days of membrane curing to that of Water curing, but there is a loss in strength of around 8\% at 28 days of membrane curing to that of Water curing. The incorporation of Metakaolin in high strength concretes reduced the percentage loss in strength because of reduced porosity.
\end{abstract}

Keywords: SCC; Metakaolin; Membrane curing; compressive strength $* * *$

\section{INTRODUCTION}

Curing of concrete is equally important to the proportioning of concrete. Curing of concrete using water becomes costlier and tedious at some places where day-to-day monitoring and inspection of curing is not possible. Liquid membrane forming curing compounds are suitable and also economical for the foundations of towers and their copings for chimneys at scattered locations, remote areas, deserts, forests, hilly terrains and across rivers, concrete structures having vertical, sloped and curved surfaces and tall chimneys and cooling towers in thermal power stations. In this study, two different curing methods viz., conventional Immersion curing and Wax based liquid membrane forming compound were used.

Self Compacting Concrete (SCC) was preferred in this research for its rapid growing utilisation. SCC has been described as the most revolutionary development in concrete construction industry because of faster construction, reduction in site manpower, better surface finishes, easier placing in densely reinforced structures, improved durability, and greater freedom in design, thinner concrete sections, reduced noise levels and absence of vibration. The concrete cubes of $100 \mathrm{~mm}$ size made up of M50 standard concrete and M80 high strength concrete of SCC with OPC only and with Metakaolin as supplementary cementing material were prepared for the tests. Metakaolin is a manufactured pozzolanic mineral admixture, which significantly enhances many performance characteristics of cement-based mortars, concretes and related products. Metakaolin is derived from purified kaolin clay, a white, amorphous, alumino-silicate, which reacts aggressively with calcium hydroxide, a normal cement hydration byproduct, to form compounds with cementitious value. Metakaolin was used as supplementary cementing material in this project.

\section{MATERIALS}

Ordinary Portland Cement of 53 Grade was used and it conforms to IS12269-1987. Fine Aggregate was river sand and conforms to zone-II as per IS 383-1970. Coarse Aggregate was $12 \mathrm{~mm}$ graded $\mathrm{HBG}$ and conforms to IS 383-1970. A white, highly pozzolanic and highly reactive Metakaolin was procured. The physical and chemical properties are given in the table 1 .

The liquid membrane forming curing compound is a wax based compound which when applied on concrete, forms a seamless film and aids in arresting the evaporation of water through the capillaries of concrete. This compound complies with ASTM C 309. This white pigmented wax based compound is effective up to 28 days. The dosage ranges between 4 to $6 \mathrm{~m}^{2} /$ litre. 
Superplasticisers, based on polycarboxylic ether polymer with long lateral chains were used and conforms to ASTM C 49492 Type $\mathrm{F}$ and also conforms to IS $9103-2007$.

Table 1 Physical and Chemical properties of Metakaolin

\begin{tabular}{|c|c|c|c|c|c|c|c|c|}
\hline \multicolumn{6}{|c|}{ Physical properties of Metakaolin } & \multicolumn{3}{|c|}{ Chemical Properties } \\
\hline 1. & Brightness & $85 \pm 1$ & 5. & Residue on $400 \mu$ & Nil & 1. & $\mathrm{SiO}_{2}$ & $52.8 \%$ \\
\hline 2. & Oil absorption (\%) & $60 \pm 5$ & 6. & Specific gravity & $2 \pm 0.1$ & 2. & $\mathrm{~A} 12 \mathrm{O} 3$ & $36.3 \%$ \\
\hline 3. & Moisture (\%) & 0.5 & 7. & Bulk Density(Kg/cum) & $320 \pm 20$ & 3. & $\mathrm{Fe} 2 \mathrm{O} 3$ & $4.21 \%$ \\
\hline 4. & Particle size: Average (d50) & $1 \pm 1$ & 8. & $\mathrm{Ph}$ of $10 \%$ solution & $6 \pm 1$ & 4. & $\mathrm{MgO}$ & $0.81 \%$ \\
\hline & $<10$ Microns $(\%)$ & $95 \pm 2$ & & & & 5. & $\mathrm{CaO}$ & $<0.10 \%$ \\
\hline & $<2$ Microns $(\%)$ & $80 \pm 1$ & & & & 6. & $\mathrm{~K}_{2} \mathrm{O}$ & $1.41 \%$ \\
\hline & & & & & & 7. & LOI & $3.53 \%$ \\
\hline
\end{tabular}

\section{PREPARATION OF SCC AND TESTS}

"The European guidelines for self compacting concrete - May 2005" were used to proportion, mix and test the fresh properties of SCC concrete. Four different SCC mixes were selected to compare the strength properties of differently cured cubes of $100 \mathrm{~mm}$ size prepared with 53 grade OPC and Metakaolin. A total number of 96 cubes were casted. Mix design approach was based on laboratory trials to verify properties of the initial mix composition with respect to the specified characteristics and classes specified in European guide lines and EFNARC. Adjustments to the mix composition were made to evaluate the demand of water and superplasticizer, sand and the dose of Metakaolin to give the required robustness and optimised the flow and stability of the paste. Redesign of the mixes was done when the performance of the mixes were not satisfactory.
After finishing the tests on fresh concrete, cubes were casted and the top surfaces of $50 \%$ of the cubes were painted with wax based liquid membrane forming curing compound when the top surfaces of concrete were felt touch dry. Next day $50 \%$ of the cubes were immersed in water pond and the 5 faces of the remaining cubes were painted with wax based liquid membrane forming curing compound @ 4Sq.mt/Litre. The tests on hardened concrete were performed at 7 days and 28 days and the test results on fresh and hardened concrete are tabulated in Table 2 and compressive strengths of both water cured and membrane cured cubes of M50 and M80 are in Tables $3 \& 4$. The comparison among strengths is shown in Bar Char 1.

Table 2 SCC Mix proportions and Compressive strengths

\begin{tabular}{|c|c|c|c|c|c|c|c|c|c|}
\hline \multicolumn{10}{|c|}{ SCC with Metakaolin \& Curing methods } \\
\hline & & \multicolumn{2}{|c|}{$\begin{array}{c}\text { Mix-1(Cement) - } \\
\text { M50 }\end{array}$} & \multicolumn{2}{|c|}{$\begin{array}{c}\text { Mix-2(C+MK) - } \\
\text { M50 }\end{array}$} & \multicolumn{2}{|c|}{$\begin{array}{c}\text { Mix-3(Cement) - } \\
\text { M80 }\end{array}$} & \multicolumn{2}{|c|}{$\begin{array}{c}\text { Mix-4(C+MK) - } \\
\text { M80 }\end{array}$} \\
\hline S.No. & Description & Quantity & Unit & Quantity & Unit & Quantity & Unit & Quantity & Unit \\
\hline 1 & Fine aggregate & 1000 & $\mathrm{Kg}$ & 735 & $\mathrm{Kg}$ & 1000 & $\mathrm{Kg}$ & 715 & $\mathrm{Kg}$ \\
\hline 2 & Coarse aggregate & 800 & $\mathrm{Kg}$ & 515 & $\mathrm{Kg}$ & 700 & $\mathrm{Kg}$ & 500 & $\mathrm{Kg}$ \\
\hline 3 & Total Binder & 500 & $\mathrm{Kg}$ & 440 & $\mathrm{Kg}$ & 800 & $\mathrm{Kg}$ & 570 & $\mathrm{Kg}$ \\
\hline 4 & Cement & 500 & $\mathrm{Kg}$ & 330 & $\mathrm{Kg}$ & 800 & $\mathrm{Kg}$ & 456 & $\mathrm{Kg}$ \\
\hline 5 & Metakaolin & 0 & $\mathrm{Kg}$ & 110 & $\mathrm{Kg}$ & 0 & $\mathrm{Kg}$ & 114 & $\mathrm{Kg}$ \\
\hline 6 & Water & 228.5 & $\mathrm{Kg}$ & 176 & $\mathrm{Kg}$ & 320 & $\mathrm{Kg}$ & 228 & $\mathrm{Kg}$ \\
\hline 7 & water/binder & 0.457 & & 0.4 & & 0.4 & & 0.4 & \\
\hline \multirow[t]{2}{*}{8} & Super plasticizer(Auramix400) & 9 & $\mathrm{Kg}$ & 4.4 & $\mathrm{Kg}$ & 6 & $\mathrm{Kg}$ & 4.4 & $\mathrm{Kg}$ \\
\hline & $\%$ SP1/Total binder= & 1.8 & $\%$ & 1 & $\%$ & 0.75 & $\%$ & 0.77 & $\%$ \\
\hline \multirow[t]{2}{*}{9} & (GleniumSky B233) & 1 & $\mathrm{Kg}$ & 1.1 & $\mathrm{Kg}$ & 0 & $\mathrm{Kg}$ & 1.1 & $\mathrm{Kg}$ \\
\hline & $\%$ SP2/Total binder= & 0.2 & $\%$ & 0.25 & $\%$ & 0 & $\%$ & 0.19 & $\%$ \\
\hline 10 & $\begin{array}{l}\text { Ref. European Guide Lines(2005) } \\
\text { CLASS(Ref: Appendix-A) }\end{array}$ & \multicolumn{2}{|c|}{$\begin{array}{l}\text { SF2, VS1/VF1, } \\
\text { PA2 - Good }\end{array}$} & \multicolumn{2}{|c|}{$\begin{array}{l}\text { SF2, VS1/VF1, } \\
\text { PA2 - Good }\end{array}$} & \multicolumn{2}{|c|}{$\begin{array}{l}\text { SF2, VS1/VF1, } \\
\text { PA2 - Good }\end{array}$} & \multicolumn{2}{|c|}{$\begin{array}{l}\text { SF2, VS1/VF1, } \\
\text { PA2 - Good }\end{array}$} \\
\hline \multirow[t]{3}{*}{11} & Compressive Strength-7days & & & & & & & & \\
\hline & Water Cured Cubes & 40.44 & $\mathrm{MPa}$ & 43.63 & $\mathrm{MPa}$ & $\mathbf{5 4 . 5 7}$ & $\mathrm{MPa}$ & 55.14 & $\mathrm{MPa}$ \\
\hline & Wax Membrane Cured Cubes & 40.53 & $\mathrm{MPa}$ & 39.64 & $\mathrm{MPa}$ & 49.6 & $\mathrm{MPa}$ & 53.7 & $\mathrm{MPa}$ \\
\hline \multirow[t]{3}{*}{12} & Compressive Strength-28days & & & & & & & & \\
\hline & Water Cured Cubes & 50.36 & $\mathrm{MPa}$ & 52.64 & $\mathrm{MPa}$ & 80.64 & $\mathrm{MPa}$ & 84.94 & $\mathrm{MPa}$ \\
\hline & Wax Membrane Cured Cubes & 46.15 & $\mathrm{MPa}$ & 46.43 & $\mathrm{MPa}$ & 59.94 & $\mathrm{MPa}$ & 69.95 & $\mathrm{MPa}$ \\
\hline
\end{tabular}


Table 3 Comparison of Compressive Strengths of SCC Mixes M50

\begin{tabular}{|l|r|r|r|r|r|r|}
\hline \multicolumn{4}{|c|}{ Mix-1 (Only Cement) Standard Concrete M50 } & \multicolumn{3}{c|}{ Mix-2 (Cement+MK) Standard Concrete M50 } \\
\hline $\begin{array}{c}\text { Age of } \\
\text { Concrete }\end{array}$ & $\begin{array}{c}\text { Water } \\
\text { Cured(MPa) }\end{array}$ & $\begin{array}{c}\text { Membrane } \\
\text { Cured(MPa) }\end{array}$ & Loss in Strength \% & $\begin{array}{c}\text { Water } \\
\text { Cured(MPa) }\end{array}$ & $\begin{array}{c}\text { Membrane } \\
\text { Curing(MPa) }\end{array}$ & \multicolumn{1}{c|}{ Loss in Strength \% } \\
\hline 7 Days & 40.44 & 40.53 & 0 & 43.63 & 39.64 & 9.15 \\
\hline 28 Days & 50.36 & 46.15 & 8.36 & 52.64 & 46.43 & 11.80 \\
\hline
\end{tabular}

Table 4 Comparison of Compressive Strengths of SCC Mixes M80

\begin{tabular}{|l|r|r|r|r|r|r|}
\hline & \multicolumn{3}{|c|}{ Mix-3 (Cement) High Strength Concrete M80 } & \multicolumn{3}{c|}{ Mix-4 (Cement+MK) High Strength Concrete M80 } \\
\hline $\begin{array}{c}\text { Age of } \\
\text { Concrete }\end{array}$ & $\begin{array}{c}\text { Water } \\
\text { Cured(MPa) }\end{array}$ & $\begin{array}{c}\text { Membrane } \\
\text { Curing(MPa) }\end{array}$ & Loss in Strength\% & $\begin{array}{c}\text { Water } \\
\text { Cured(MPa) }\end{array}$ & $\begin{array}{c}\text { Membrane } \\
\text { Curing(MPa) }\end{array}$ & Loss in Strength \% \\
\hline 7 Days & 54.57 & 49.6 & 9.11 & 55.14 & 53.7 & 2.61 \\
\hline 28 Days & 80.64 & 59.94 & 25.67 & 84.94 & 69.95 & 14.99 \\
\hline
\end{tabular}

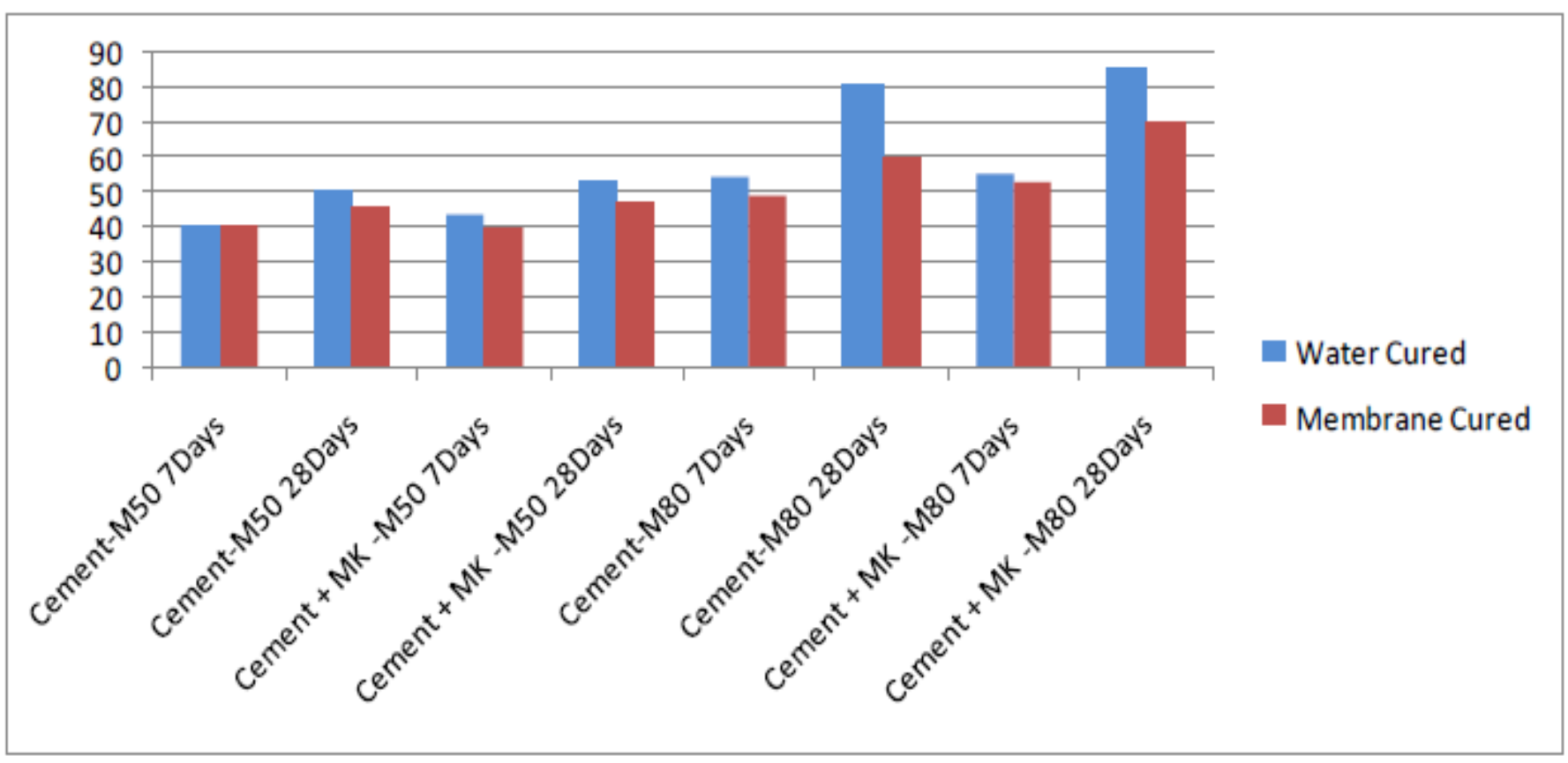

Bar Chart 1 Comparison of Compressive Strengths of Mixes for Water cured \& Membrane cured cubes

\section{ANALYSIS ON RESULTS}

1. SCC made with OPC 53 grade using a total binder content of $500 \mathrm{~kg}$ (OPC) gave a standard concrete grade of M50 (Mix-1) and using a total binder content of $800 \mathrm{~kg}$ (OPC) gave a high strength concrete grade of M80 (Mix$3)$. The difference in compressive strengths of water and membrane cured cubes of Mix-1 at 7 days is nil, but there is a difference of $8.36 \%$ at 28 days of curing. The difference in compressive strengths of water and membrane cured cubes of Mix-3 at 7 days is $9.11 \%$, and there is a difference of $25.67 \%$ at 28 days of curing. An average difference of $3 \%$ in the weights among the water and membrane cured cubes of both M50 and M80 grade was observed.

2. SCC made with OPC 53 grade $(330 \mathrm{Kg})$ and Metakaolin $(110 \mathrm{Kg})$ as SCM using a total binder content of $440 \mathrm{~kg}$ gave a standard concrete grade of M50 (Mix-2). SCC made with OPC 53 grade $(456 \mathrm{Kg})$ and Metakaolin $(114 \mathrm{Kg})$ as SCM using a total binder content of $570 \mathrm{~kg}$ gave a high strength concrete grade of M80 (Mix-4). The difference in compressive strengths of water and membrane cured cubes of Mix-2 at 7 days is $9.15 \%$, but there is a difference of $11.86 \%$ at 28 days of curing. The difference in compressive strengths of water and membrane cured cubes of Mix-4 at 7 days is $2.61 \%$, and there is a difference of $14.99 \%$ at 28 days of curing. Average differences of $7.5 \%$ and $2.7 \%$ were observed in the weights among the water and membrane cured cubes of M50 grade and M80 grade, respectively.

3. Comparing the Mix-1 and Mix-2 of similar grades of M50, the loss in strength for Mix-2 is more compared to Mix-1 i.e. $9.15 \%$ at 7 days of age and $3.44 \%$ at 28 
days of age of Membrane cured cubes. The rate of loss in strength is more in Mix-1 (8.36\% in 21 days), but the rate of loss in strength is less in Mix-2 (11.8-9.15=3.65\% in 21days). Comparing the Mix-3 and Mix-4 of similar grades of M80, the loss in strength for Mix-3 is more compared to Mix-4 i.e. $9.11 \%$ for Mix-3 and $2.61 \%$ for Mix-4 at 7 days of age and $25.67 \%$ for Mix-3 and $14.99 \%$ for Mix-4 at 28 days of age of Membrane cured cubes. The rate of loss is more in Mix-3 (25.67$9.11=16.56 \%$ in 21 days), but the rate of loss is less in Mix-4 (14.99-2.61=12.38\% in 21days).

\section{CONCLUSION}

1. The rate of loss in strength per day is less after 7 days of membrane curing of SCC cubes made with Metakaolin as SCM, is due to the gaining in strength when portlandite is reacting with Metakaolin to form C-S-H and ettringite.

2. The loss in strength is more in membrane cured high strength concrete, M80 grade SCC cubes made with OPC, when compared to membrane cured standard concrete, M50 grade SCC cubes made with OPC, because more heat of hydration in M80 high strength concrete.

3. The loss in strength is less in membrane cured high strength concrete, M80 grade SCC cubes made with OPC and Metakaolin as SCM, when compared to membrane cured high strength concrete, M80 grade SCC cubes made with OPC only. This may be due to the reduced porosity of concrete due to Metakaolin.
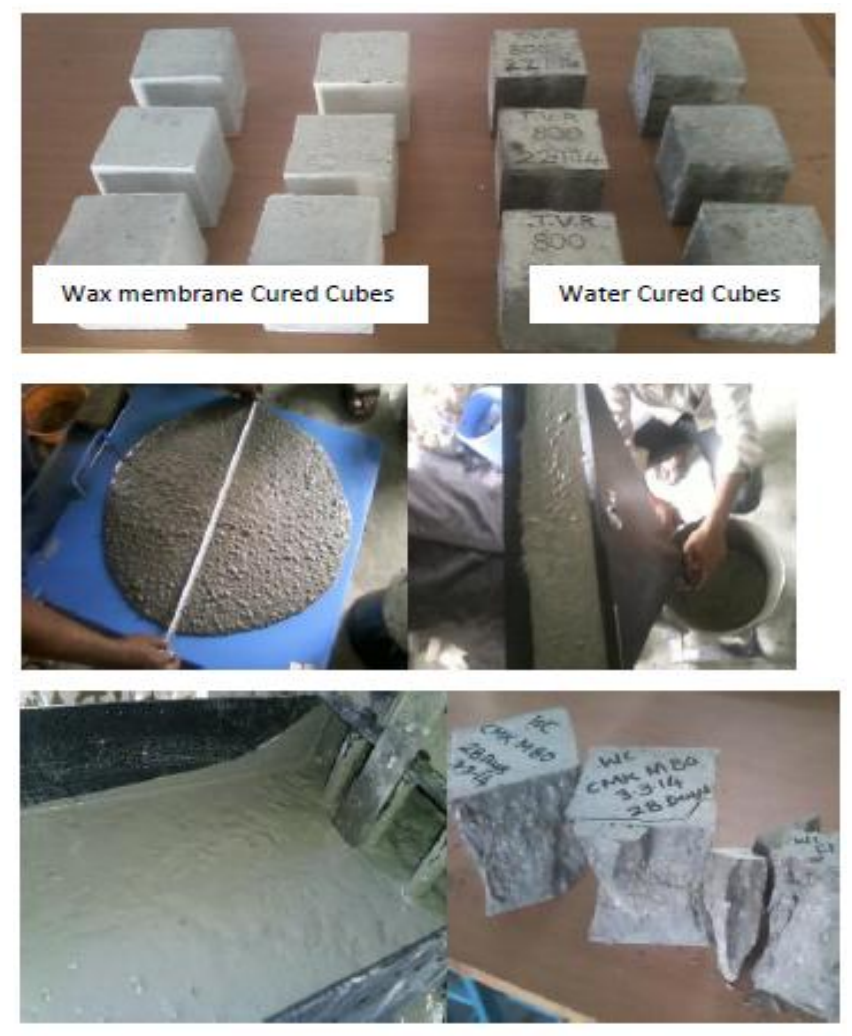

PHOTOGRAPHS

\section{REFERENCES}

[1] ASCE Journal October 2013-Application of Statistical Analysis for Mixture Design of HighStrength Self-Consolidating Concrete Containing Metakaolin by Ahmed A.Abouhussien, M.A.Sc.1 and Assem A.A.Hassan, Ph.D., M.A.Sc., M.Sc.2* Faculty of Engineering and Applied Science, Memorial University ofNewfoundland,St.John's, Newfoundland, Canada.

[2] ASCE Journal, April 2013-Study of Robustness of Self-Compacting Concretes Made with Low Fines Content by L.García1; M.Valcuende, Ph.D.2; S.Balasch,Ph.D.3; and J.Fernández-LLebrez-4,Dept. of Architectural Constructions, Universidad Politecnica de Valencia, Spain.

[3] ASCE Journal, October 2010 - Fresh and Hardened Properties of SCC Made with Different Aggregate and Mineral Admixtures by Selcuk Turkel and Ali Kandemir, Dept. of Civil Engineering, Dokuz Eylul University, Izmir, Turkey

[4] ASCE Journal, November, 2013 - Properties of SelfConsolidating Concrete Made with High Volumes of Supplementary Cementitious Materials by Hassan El-Chabib and Adnan Syed, Dept. of Civil Engineering and Construction, Bradley Univ., Peoria, ILLINOIS.

[5] ASCE Journal, November, 2013 - Ultra strength Flowable Concrete Made with High Volumes of Supplementary Cementitious Materials by Ahmed Ibrahim, Ph.D., A.M.ASCE; Hassan El-Chabib, Ph.D., and Ahmed Eisa, Ph.D., Dept. of Civil Engineering and Construction, Bradley Univ., Peoria, ILLINOIS.

[6] IJRET May-2015- Hydration mechanism and strength of OPC and blended OPC with Fly ash in the presence of Metakaolin- Anamika Singh, Sukirti Gupta, Jahnavi Singh and N.P.Singh, Department of Chemistry, UPA college, Varanasi.

[7] FACTA UNIVERSITATIS-2010- A study on the influence of curing on the strength of a standard grade concrete mix-M.V.Krishna Rao (CBIT), P.Ratish Kumar (NIT,Warangal) \& Azhar M.Khan (NIT,Warangal). 
APPENDIX - A

\begin{tabular}{|l|l|l|l|l|}
\hline $\begin{array}{l}\text { Slump-Flow classes } \\
\text { Class }\end{array}$ & Slump-flow in $\mathrm{mm}$ & Viscosity classes Class & $\mathrm{T}_{500}, \mathrm{~s}$ & $\mathrm{~V}$-funnel time in $\mathrm{s}$ \\
\hline $\mathrm{SF} 1$ & 550 to 650 & $\mathrm{VS} 1 / \mathrm{VF} 1$ & $\leq 2$ & $\leq 8$ \\
\hline $\mathrm{SF} 2$ & 660 to 750 & $\mathrm{VS} 2 / \mathrm{VF} 2$ & $>2$ & 9 to 25 \\
\hline SF3 & 760 to 850 & & & \\
\hline $\begin{array}{l}\text { Passing ability classes } \\
\text { (L-box) Class }\end{array}$ & Passing ability & & & \\
\hline PA1 & $\geq 0,80$ with 2 rebars & & & \\
\hline PA2 & $\geq 0,80$ with 3 rebars & & & \\
\hline
\end{tabular}

